\title{
ANALISIS DAMPAK KENAIKAN UPAH MINIMUM PROVINSI, TERHADAP TINGKAT PENGANGGURAN DAN TINGKAT PARTISIPASI ANGKATAN KERJA DI JAKARTA $2004-2013$
}

\author{
Niddaul Izzah \\ Institut Ilmu Sosial dan Manajemen STIAMI \\ nida.achis@yahoo.com
}

\begin{abstract}
Abstrak. Penelitian ini menganalisis dampak kenaikan upah minimum provinsi terhadap tingkat partisipasi angkatan kerja di Jakarta. Hasil penelitian menunjukkan kenaikkan Upah Minimum Provinsi dapat menurunkan tingkat pengangguran dan menaikkan tingkat partisipasi angkatan kerja di Jakarta. Untuk menurunkan tingkat pengangguran di Jakarta maka sebaiknya upah minimum provinsi besarnya selalu disesuaikan dengan standar hidup yang layak. Menurunnya tingkat pengangguran akan berdampak luas terhadap masalah sosial, ekonomi, dan keamanan di Jakarta.
\end{abstract}

Kata kunci: Upah Minimum, Pengangguran, Partisipasi Angkatan Kerja

Abstract. This study analyzesthe impact of minimum wage increases to the provincial labor force participation rate in Jakarta. The results showed the increase in provincial minimum wage can reduce unemployment and raiselabor force participation rate in Jakarta. To lower the unemployment rate in Jakarta, the provincial minimum wage should always be adjusted to the size of a decent standard of living. The unemployment rate would have a wide impacton the social, economic, and security in Jakarta.

Keywords: MinimumWages, Unemployment, Labor Force Participation

Sebuah perusahaan dalam perjalanan bisnisnya akan sering menghadapi tekanan. Berbagai tekanan yang datang bukan hanya berasal dari eksternal perusahaan, tidak jarang tekanan malah justru banyak ditimbulkan oleh faktor internal perusahaan. Tekanan dari internal ataupun eksternal perusahaan sebenarnya dapat dihadapi bila perusahaan sebisa mungkin selalu menciptakan dan menjaga hubungan baik melalui komunikasi "bebas hambatan" dengan kedua belah pihak .

Kisruh dalam masalah pengupahan yang beberapa tahun ini merebak dengan seringnya terjadi demo buruh, merupakan indikasi adanya komunikasi yang tidak terjalin dengan baik antara pengusaha dengan buruh/karyawan. Aksi demo buruh dengan melakukan mogok kerja dan sweeping akan memukuliklim investasi nasional. Investor akan melihat Indonesia bukan sebagai negara yang kondusif untuk menanamkan modal mereka. Padahal datangnya investasi akan dapat menyerap tenaga kerja sekaligus menekan angka pengangguran nasional.

Karyawan merupakan aset penting yang dimiliki perusahaan. Sekalipun tidak mempunyai pengaruh besar dalam proses pengambilan keputusan, karyawan adalah aset yang paling penting di dalam suatu perusahaan. Tanpa karyawan atau sumber daya manusia di adalam perusahaan faktor-faktor produksi yang lain tidak dapat difungsikan dengan efektif dan efisien. Hal ini harus menjadi pemikiran bagi para pengusaha agar dapat memperlakukan karyawannya sebaik-baiknya. Karyawan yang diperlakukan dengan baik oleh pengusaha akan memberikan timbal balik yang positif bagi perusahaan melalui kinerjanya. Sebaliknya karyawan yang merasa tidak diperhatikan atau merasa tidak mendapat simpati dari perusahaan akan dapat merugikan perusahaan. Kedudukan struktural yang lemah, biasanya membuat para karyawan membentuk sebuah kelompok/paguyuban informal yang fungsinya adalah membela kepentingan para karyawan. Kelompok inilah yang umumnya menjadi penggerak karyawan dalam melakukan gerakan protes atau yang sejenis lainnya. Karyawan yang bersatu dan merasa hak-hak mereka tidak mendapat perhatian dari Top Management biasanya akan menjadi sangat sensitif. Para karyawan yang tidak puas terhadap keputusan / 
kebijakan perusahaan dapat melakukan tindakan-tindakan yang merugikan perusahaan, misalnya pemogokan masal.

Meskipun tenaga kerja merupakan sumber daya yang penting bagi perusahaan, namun hubungan yang terjadi haruslah selau bersifat saling menguntungkan. Pengusaha membutuhkan karyawan untuk menggerakkan roda kehidupan perusahaan sehingga timbul kewajiban untuk membayar upah/gaji, sebaliknya karyawan juga membutuhkan pengusaha untuk memperoleh penghasilan yang dapat digunakan untuk menghidupi dirinya sendiri dan keluarganya. Oleh karena itu karyawan juga mempunyai kewajiban untuk meningkatkan produktivitasnya.

Jika semua pihak saling menyadari akan adanya rasa saling membutuhkan mestinya demo buruh tidak perlu terjadi. Pengusaha seharusnya memberikan upah sesuai dengan sumbangan yang diberikan karyawan dalam pencapaian laba perusahaan, karyawan pun harus menyadari seberapa besar andilnya dalam memajukan perusahaan. para pengusaha dan buruh perlu segera menghentikan perselisihan karena hal itu sangat tidak produktif. Kedua pihak perlu meningkatkan toleransi dan semangat kebersamaan demi terciptanya formula pengupahan yang akseptabel.

Pengupahan yang akseptabel merupakan kesepakatan kedua belh pihak setelah menyadari adanya hubungan saling membutuhkan dan tidak saling merugikan. Pengupahan selayaknya terjadi pada harga kesimbangan.

Dalam hukum ekonomi dikenal adanya kurva permintaan dan kurva penawaran. Karyawan dalam pasar tenaga kerja dapat disebut sebagai penjual jasa, dan pengusaha merupakan pembeli jasa. Sesuai dengan hukum permintaan, pengusaha akan mau membeli jika harga yang ditawarkan oleh penjual berada pada harga ekuilibrium dan akan semakin meningkat pembeliannya jika harga berada di bawah garis ekuilibrium. Sebaliknya penjual akan mau menjual jasanya jika harga berada pada posisi ekuibrium dan akan semakin banyak penjual jika harga di pasar di atas ekuilibrium.

AW. Philips pada tahun 1958 membuat studi mengenai ciri-ciri perubahan tingkat upah dan tingkat pengangguran, Kesimpulan dari studi ini adalah bahwa terdapat hubungan yang negatif di antara kenaikan upah dengan tingkat pengangguran. Pada saat tingkat pengangguran tinggi, dan pada saat tingkat pengangguran rendah, persentase kenaikan upah meningkat. (Sadono Sukirno, 2006: 245-246).

Data tentang besarnya upah minimum Provinsi DKI pada tahun 2011 melalui Pergub DKI No 196 Tahun 2010 tentang upah minimum provinsi Daerah Khusus Ibukota Jakarta Tahun 2011 per tanggal 15 November 2010 menetapkan UMP DKI tahun 2011 sebesar Rp1.290.000,- per bulan per orang atau naik sebesar 15,38 persen dari UMP DKI tahun 2010 yang hanya sebesar Rp 1.118.009,- per bulan per orang. sebesar Rp1.290.000,- tahun 2012 naik 18,53 \% menjadi sebesar Rp1.529.150,- (Pergub DKI Jakarta Nomor 117 Tahun 2011 Tentang UMP per 28 November 2011) dan pada tahun 2013 naik sebesar 43,88 $\%$ menjadi Rp2.200.000,-

Wakil Ketua Umum Kamar Dagang dan Industri DKI Jakarta Sarman Simanjorang, Minggu (24/3), di Jakarta. Mengatakan bulan Maret 2013 sebanyak 3.447 buruh menjadi korban rasionalisasi, dan sampai akhir tahun diperkirakan sebanyak 22.567 orang akan kehilangan pekerjaan dari 41 perusahaan. Tingginya upah minimum dinilai menjadi pemicunya. Jika UMP (upahminimum provinsi) tahun 2014 naik lagi, kemungkinan semua perusahaan yang ada di Kawasan Berikat Nusantara (KBN) akan tutup. (Kompas, 25 Maret 2013).

Penelitian ini akan menjawab pertanyaan-pertanyaan sebagai berikut: (1) Bagaimana kebijakan pengupahan di Jakarta tahun 2004-2013? (2) Bagaimana pergerakan angka pengangguran di Jakarta tahun 2004 2013 ? (3) Bagaimana pergerakan tingkat partisipasi angkatan kerja di Jakarta tahun 2004 -2013? (4) Bagaimana dampak kenaikan upah minimum provinsi terhadap tingkat pengagguran di Jakarta di Jakarta? (5) Bagaimana dampak kenaikan upah minimum provinsi terhadap tingkat partisipasi angkatan kerja di Jakarta? 


\section{KAJIAN LITERATUR}

\section{Upah / Gaji}

Tenaga kerja atau sumber daya manausia dalam suatu organisasi memegang peranan yang sangat penting dibandingkan dengan sumber daya yang lain. Tanpa tenaga kerja faktor-faktor produksi yang lain tidak dapat difungsikan secara maksimal. Salah satu tugas dari manajemen sumber daya manusia adalah memelihara karyawan yang ada agar terjadi hubungan yang harmonis antara pengusaha dan karyawannya yang dapat berimbas pada produktifitas perusahaan.Pengaturan kompensasi merupakan faktor penting untuk dapat menarik, memelihara, maupun mempertahankan tenaga kerja bagi kepentingan organisasi perusahaan yang bersangkutan.

Kompensasi adalah segala sesuatu yang diterima oleh karyawan sebagai balas jasa kerja mereka (Sedarmayanti, 2011: 239)

Kompensasi adalah segala sesuatu yang diterima oleh karyawan sebagai balas jasa atas kontribusinya kepada perusahaan atau organisasi . Kompensasi dapat bersifat finansial seperti upah dan gaji maupun non finansial (I Komang Ardana, 2012: 153).

Upah adalah imbalan kepada buruh yang melakukan pekerjaan kasar dan lebih banyak mengandalkan kekuatan fisik dan biasanya jumlahnya ditetapkan secara harian, satuan atau borongan (Soemarso , 2009: 307)

Upah umumnya merupakan pembayaran atas penyerahan jasa yang dilakukan oleh karyawan pelaksana/buruh (Mulyadi, 2008: 373)

Upah/gaji adalah hak pekerja/buruh yang diterima dan dinyatakan dalam bentuk uang sebagai imbalan dari pengusaha atau pemberi kerja kepada pekerja/buruh yang ditetapkan dan dibayarkan menurut suatu perjanjian kerja, kesepakan, atau peraturan atau perundang-undangan termasuk tunjangan bagi pekerja/buruh dan keluarganya atas suatu pekerjaandan/atau jasa telah atau akan dilakukan. (Saifuddin Bachrun, 2012: 2)

Bagi pengusaha, gaji atau upah dapat dianggap sebagai biaya murni sehingga akan diperhitungkan secara matang dengan pertimbangan aspek biaya dan bisnis dan akan menekan biaya produksi sehemat mungkin.. Namun jika gaji atau upah dianggap sebagai bagian dari investasi sumber daya manusia, maka pengusaha akan berpikir jangka panjang terkait dengan hubungan kerja dan hubungan industrial.

Bagi tenaga kerja gaji atau upah berkaitan dengan keinginan dan kebutuhan yang semakin bertambah seiring lamanya masa kerja atau yang sering dianggap sebagai masa pengabdian. Saefuddin menggambarkan hubungan masa kerja, status pekerja dan kebutuhan pekerja seperti pada tabel 1 .

Perbedaan cara pandang anatara pengusaha dengan pekerja dalam masalah upah dan gaji seringkali menimbulkan konflik. Peran pemerintah sebagai regulator sangat diperlukan untuk mengakomodir kepentingan tenaga kerja dan pengusaha. Masalah pengupahan telah diatur dalam Undang-undang Republik Indonesia Nomor 13 Tahun 2003 tentang ketenagakerjaan pasal 88 sampai pasal 98.

\section{Pasal 88}

(1) Setiap pekerja/buruh berhak memperoleh penghasilan yang memenuhi penghidupan yang layak bagi kemanusiaan.

(2) Untuk mewujudkan penghasilan yang memenuhi penghidupan yang layak bagi kemanusiaan sebagaimana dimaksud dalam ayat (1), pemerintah menetapkan kebijakan pengupahan yang melindungi pekerja/buruh.

(3) Kebijakan pengupahan yang melindungi pekerja/buruh sebagaimana dimaksud dalam ayat (2) meliputi :
a. Upah minimum;
b. Upah kerja lembur;
c. upah tidak masuk kerja karena berhalangan;
d. upah tidak masuk kerja karena melakukan kegiatan lain di luar pekerjaannya;
e. upah karena menjalankan hak waktu istirahat kerjanya;
f. bentuk dan cara pembayaran upah;
g. denda dan potongan upah; 
Niddaul Izzah, Analisis Dampak Kenaikan Upah Minimum Provinsi

Tabel 1. Hubungan Masa Kerja, Status Pekerja dan Kebutuhan Pekerja

\begin{tabular}{|c|c|c|}
\hline Masa Kerja & Status Pekerja & Kebutuhan Pekerja \\
\hline$<2$ tahun & Lajang & $\begin{array}{l}\text { - Gaji } \\
\text { - Tunjangan transport } \\
\text { - Makan siang }\end{array}$ \\
\hline $2-4$ tahun & Menikah & $\begin{array}{l}\text { - Gaji } \\
\text { - Tunjangan transport } \\
\text { - Makan siang } \\
\text { - Biaya kesehatan } \\
\text { - Biaya sewa rumah }\end{array}$ \\
\hline $5-7$ tahun & Menikah dan anak 1 atau 2 & $\begin{array}{l}\text { - Gaji } \\
\text { - Tunjangan transport } \\
\text { - Makan siang } \\
\text { - Biaya kesehatan } \\
\text { - Biaya sewa rumah } \\
\text { - Biaya kelahiran } \\
\text { - Biaya komunikasi } \\
\text { - Biaya dokter keluarga } \\
\text { - Biaya pulang kampung }\end{array}$ \\
\hline$>7$ tahun & Menikah, ada anak, dan anak bersekolah & $\begin{array}{l}\text { - Gaji } \\
\text { - Tunjangan transport } \\
\text { - Makan siang } \\
\text { - Biaya kesehatan } \\
\text { - Biaya sewa rumah } \\
\text { - Biaya kelahiran } \\
\text { - Biaya komunikasi } \\
\text { - Biaya dokter keluarga } \\
\text { - Biaya pulang kampung } \\
\text { - Biaya sekolah } \\
\text { - pensiun }\end{array}$ \\
\hline
\end{tabular}

h. hal-hal yang dapat diperhitungkan dengan upah;

i. struktur dan skala pengupahan yang proporsional;

j. upah untuk pembayaran pesangon; dan

k. upah untuk perhitungan pajak penghasilan

(4) Pemerintah menetapkan upah minimum sebagaimana dimaksud dalam ayat (3) huruf a berdasarkan kebutuhan hidup layak dan dengan mem-perhatikan produktivitas dan pertumbuhan ekonomi.

\section{Pasal 89}

(1) Upah minimum sebagaimana dimaksud dalam Pasal 88 ayat (3) huruf a dapat terdiri atas:

a. upah minimum berdasarkan wilayah provinsi atau kabupaten/kota;

b. upah minimum berdasarkan sektor pada wilayah provinsi atau kabupaten/kota.

(2) Upah minimum sebagaimana dimaksud dalam ayat (1) diarahkan kepada pencapaian kebutuhan hidup layak.

(3) Upah minimum sebagaimana dimaksud dalam ayat (1) ditetapkan oleh Gubernur 
dengan memperhatikan rekomendasi dari Dewan Pengupahan Provinsi dan/atau Bupati/Walikota.

(4) Komponen serta pelaksanaan tahapan pencapaian kebutuhan hidup layak sebagaimana dimaksud dalam ayat (2) diatur dengan Keputusan Menteri.

\section{Pasal 90}

(1) Pengusaha dilarang membayar upah lebih rendah dari upah minimum sebagaimana dimaksud dalam Pasal 89.

(2) Bagi pengusaha yang tidak mampu membayar upah minimum sebagaimana dimaksud dalam Pasal 89 dapat dilakukan penangguhan.

(3) Tata cara penangguhan sebagaimana dimaksud dalam ayat (2) diatur dengan Keputusan Menteri.

\section{Pasal 91}

(1) Pengaturan pengupahan yang ditetapkan atas kesepakatan antara pengusaha dan pekerja/buruh atau serikat pekerja/serikat buruh tidak boleh lebih rendah dari ketentuan pengupahan yang ditetapkan peraturan perundang-undangan yang berlaku.

(2) Dalam hal kesepakatan sebagaimana dimaksud dalam ayat (1) lebih rendah atau bertentangan dengan peraturan perundang-undangan, kesepakatan tersebut batal demi hukum, dan pengusaha wajib membayar upah

(3) pekerja/buruh menurut peraturan perundang-undangan yang berlaku.

Dalam Undang-undang RI No.13 tahun 2003 dijelaskan pengertian sebagai berikut :

1. yang berhubungan dengan tenaga kerja pada waktu sebelum, selama, dan sesudah masa kerja.

2. Tenaga kerja adalah setiap orang yang mampu melakukan pekerjaan guna menghasilkan barang dan/atau jasa baik untuk memenuhi kebutuhan sendiri maupun untuk masyarakat.
3. Pekerja/buruh adalah setiap orang yang bekerja dengan menerima upah atau imbalan dalam bentuk lain.

4. Pemberi kerja adalah orang perseorangan, pengusaha, badan hukum, atau badanbadan lainnya yang mempekerjakan tenaga kerja dengan membayar upah atau imbalan dalam bentuk lain.

5. Pengusaha adalah:

a. orang perseorangan, persekutuan, atau badan hukum yang menjalankan suatu perusahaan milik sendiri;

b. orang perseorangan, persekutuan, atau badan hukum yang secara berdiri sendiri menjalankan perusahaan bukan miliknya;

c. orang perseorangan, persekutuan, atau badan hukum yang berada di Indonesia mewakili perusahaan sebagaimana dimaksud dalam huruf a dan $b$ yang berkedudukan di luar wilayah Indonesia.

6. Perusahaan adalah:

a. setiap bentuk usaha yang berbadan hukum atau tidak, milik orang perseorangan, milik persekutuan, atau milik badan hukum, baik milik swasta maupun milik negara yang mempekerjakan pekerja/buruh dengan membayar upah atau imbalan dalam bentuk lain;

b. usaha-usaha sosial dan usaha-usaha lain yang mempunyai pengurus dan mempekerjakan orang lain dengan membayar upah atau imbalan dalam bentuk lain.

7. Upah adalah hak pekerja/buruh yang diterima dan dinyatakan dalam bentuk uang sebagai imbalan dari pengusaha atau pemberi kerja kepada pekerja/buruh yang ditetapkan dan dibayarkan menurut suatu perjanjian kerja, kesepakatan, atau peraturan perundang undangan, termasuk tunjangan bagi pekerja/buruh dan keluarganya atas suatu pekerjaan dan/atau jasa yang telah atau akan dilakukan

Peraturan Menteri Tenaga Kerja Dan Transmigrasi Nomor 7 Tahun 2013 Tentang upah minimum menyatakan: 
a. Upah minimum adalah upah bulanan terendah yang terdiri atas upah pokok termasuk tunjangan tetap yang ditetapkan oleh Gubernur sebagai jaring pengaman/

b. Upah Minimum Provinsi yang selanjutnya disingkat UMP adalah upah minimum yang berlaku untuk seluruh kabupaten/Kota di satu Provinsi.

Faktor-faktor yang memengaruhi pemberian kompensasi (Hasibuan, 2003: 127)

1. Penawaran dan permintaan tenaga kerja,

2. Kemampuan dan kesediaan karyawan,

3. Serikat buruh atau organisasi karyawan,

4. Produktifitas kerja karyawan,

5. Pemerintah dengan undang-undang dan Keppres,

6. Biaya hidup atau cost living,

7. Posisi jabatan karyawan,

8. pendidikan dan pengalaman kerja,

9. Kondisi perekonomian nasional,

10. Jenis dan sifat pekerjaan.

\section{Teori Pasar Kompetitif atau Pasar Persaingan Sempurna}

Pasar kompetitif adalah pasar yang di dalamnya terdapat banyak pembeli dan penjual, sehingga masing-masing pembeli atau penjual memiliki pengaruh yang sangat kecil terhadap harga pasar (Mankiw, 2006). Asumsikan bahwa ini adalah pasar tenaga kerja sehingga penjualnya adalah tenaga kerja dan pembelinya adalah pengusaha, sedangkan harga adalah upah. Jumlah permintaan (quantity demanded) dari suatu barang (dalam hal ini adalah permintaan akan tenaga kerja) adalah jumlah barang yang rela dan mampu dibayar oleh pembeli (pengusaha). Dengan kata lain jumlah permintaan berhubungan secara negatif terhadap harga (upah) (Mankiw, 2006).

Ketika upah minimum dari tenaga kerja tersebut lebih tinggi daripada tingkat upah keseimbangan maka permintaan akan tenaga kerja tersebut oleh pengusaha akan cenderung turun yang berarti kesempatan kerja juga mengalami penurunan. Sebaliknya jika upah minimum dari tenaga kerja tersebut lebih rendah dibandingkan tingkat upah kesimbangan maka permintaan akan tenaga kerja oleh pengusaha dan kesempatan kerja akan meningkat. Sedangkan untuk jumlah penawaran (quantity supplied) tenaga kerja adalah jumlah tenaga kerja yang mampu ditawarkan kepada pengusaha dan salah satu penentunya adalah harga dari tenaga kerja itu yaitu upah. Jumlah penawaran berhubungan secara positif dengan harga (Mankiw, 2006).

\section{Teori Upah-Efisiensi}

Mankiw (2006) menjelaskan bahwa teori upah-efisiensi mengajukan penyebab ketiga dari kekakuan upah selain undangundang upah minimum dan pembentukkan serikat pekerja. Teori upah-efisiensi yang pertama menyatakan bahwa upah yang tinggi membuat para pekerja lebih produktif. Pengaruh upah terhadap efisiensi pekerja dapat menjelaskan kegagalan perusahaan untuk memangkas upah meskipun terjadi kelebihan penawaran tenaga kerja. Meskipun akan mengurangi tagihan upah perusahaan, (jika teori ini benar) maka pengurangan upah akan memperendah produktivitas pekerja dan laba perusahaan. Teori upah-efisiensi yang kedua, menyatakan bahwa upah yang tinggi menurunkan perputaran tenaga kerja. Dengan membayar upah yang tinggi, perusahaan mengurangi frekuensi pekerja yang keluar dari pekerjaan, sekaligus mengurangi waktu yang dibutuhkan perusahaan untuk menarik dan melatih pekerja baru. Teori upah-efisiensi yang ketiga menyatakan bahwa kualitas rata-rata tenaga kerja perusahaan bergantung pada upah yang dibayar kepada karyawannya. Jika perusahaan mengurangi upahnya, maka pekerja terbaik bisa mengambil pekerjaan di tempat lain, meninggalkan perusahaan dengan pekerja yang tidak terdidik yang memiliki lebih sedikit alternatif. Dan teori upah-efisiensi yang keempat menyatakan bahwa upah yang tinggi meningkatkan upaya pekerja. Teori ini menegaskan bahwa perusahaan tidak dapat memantau dengan sempurna upaya para pekerja, dan para pekerja harus memutuskan sendiri sejauh mana mereka akan bekerja keras. Semakin tinggi upah, semakin besar kerugian bagi pekerja bila mereka sampai dipecat. Dengan membayar upah yang lebih tinggi, perusahaan memotivasi lebih banyak pekerja 


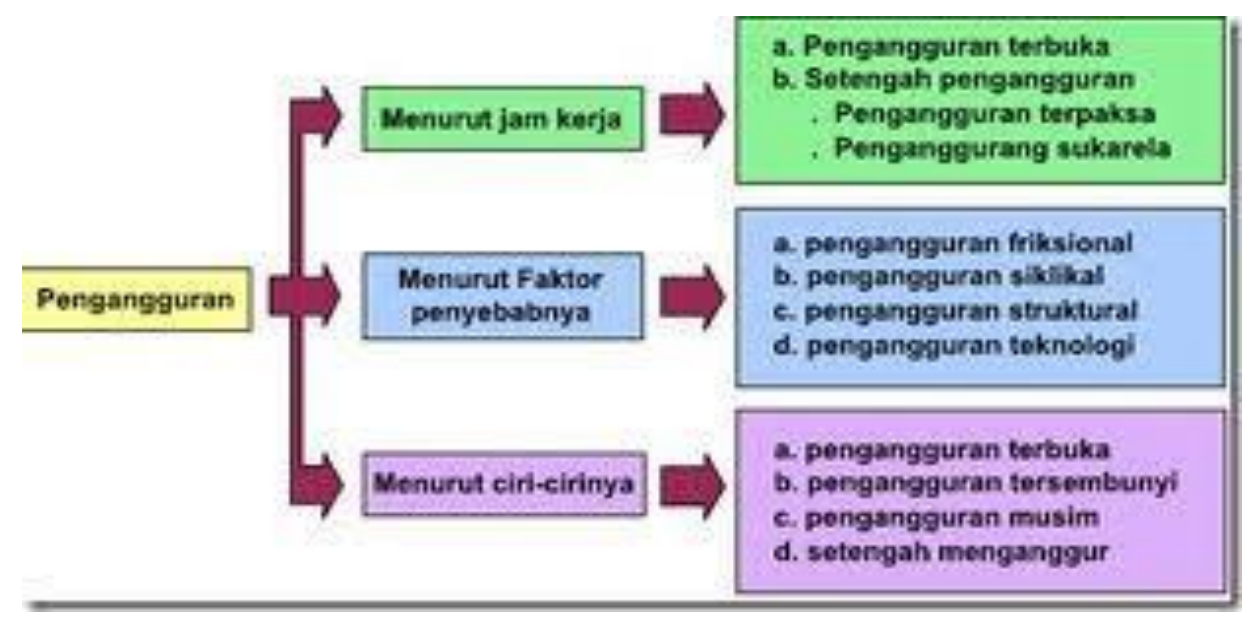

Gambar 1. Pengangguran

agar tidak bermalas-malasan dan dengan demikian meningkatkan produktivitas mereka. Meskipun keempat teori upah-efisiensi ini secara rinci berbeda, namun teori-teori tersebut menyuarakan topik yang sama: karena perusahaan beroperasi lebih efisien jika membayar pekerjanya dengan upah yang tinggi, maka perusahaan dapat menganggap bahwa mempertahankan upah di atas tingkat yang menyeimbangkan penawaran dan permintaan adalah menguntungkan.

\section{Pengangguran}

Masalah ekonomi yang sering diangkat menjadi komoditas politik akhir-akhir ini adalah masalah pengangguran, disamping masalah inflasi dan pertumbuhan ekonomi.

Penganggur adalah mereka yang tidak bekerja dan sedang mencari pekerjaan menurut referensi waktu tertentu atau mereka yang pernah bekerja / dibebastugaskan tetapi sedang menganggur dan mencari pekerjaan. (Sedarmayanti, 2011: 2)

Upaya perubahan struktural yang dilakukan pemerintah untuk meningkatkan produktivitas dan menciptakan kesempatan kerja sebagai usaha peningkatan kesejahteraan penduduk seringkali tidak dapat menjangkau seluruh elemen penduduk itu sendiri. Kesempatan dan peluang yang dimiliki tiap penduduk tentu berbeda satu dengan lainnya. Demikian pula dalam proses pembangunan, masalah-masalah seperti kemiskinan dan pengangguran merupakan ekses negatif dari pelaksanaan pembangunan seperti juga terciptanya kesenjangan sosial. Masalah pengangguran umumnya lebih banyak dicirikan oleh daerah perkotaan sebagai efek dari industrialisasi. Pengangguran terjadi sebagai akibat dari tidak sempurnanya pasar tenaga kerja, atau tidak mampunya pasar tenaga kerja dalam menyerap tenaga kerja yang ada. Akibatnya timbul sejumlah pekerja yang tidak diberdayakan dalam kegiatan perekonomian. Ini merupakan akibat tidak langsung dari supply (penawaran) tenaga kerja di pasar tenaga kerja melebihi demand (permintaan) tenaga kerja untuk mengisi kesempatan kerja yang tercipta.

Indikator yang biasa digunakan untuk mengukur pengangguran adalah Tingkat Pengangguran Terbuka (TPT). Tingkat pengangguran terbuka umumnya didefinisikan secara konvensional sebagai proporsi angkatan kerja yang tidak bekerja dan mencari pekerjaan. Ukuran ini dapat digunakan untuk mengindikasikan seberapa besar penawaran kerja yang tidak dapat terserap dalam pasar kerja di sebuah negara atau wilayah. Sumber: Sakernas

Tenaga kerja adalah penduduk pada usia kerja (15 tahun ke atas) atau 15 - 64 tahun, atau penduduk yang secara potensial dapat bekerja. (Sedarmayanti, 2011: 1).

Tenaga kerja terdiri dari:

1. Angkatan kerja yaitu penduduk yang bekerja dan yang tidak bekerja tetapi sedang mencari kerja; 
2. Bukan angkatan kerja yaitu penduduk usia kerja namun masih sekolah, mengurus rumah tangga golongan lain atau penerima pendapatan tidak tetap.

Tingkat Partisipasi Kerja (TPAK) merupakan rasio antara penduduk yang termasuk angkatan kerja (bekerja atau mencari pekerjaan) dengan total penduduk yang masuk usia kerja. Data TPAK ini sangat penting untuk peramalan struktur dan keadaan angkatan kerja pada masa yang akan datang. dalam pembangunan nasional, perencanaan pembangunan di bidang ketenagakerjaan ditekankan pada tiga masalah pokok, yaitu: perluasan lapangan kerja, peningkatan kualitas dan kemampuan tenaga kerja, serta perlindungan tenaga kerja. Semakin akurat data peramalan TPAK, semakin baik pula perencanaan yang dihasilkan.

\section{Hubungan Tingkat Upah dengan tingkat pengangguran}

Tokoh yang pertama kali meneliti hubungan tingkat upah dengan tingkat pengangguran adalah A.W.Phillips tahun 1958 dimana dari hasil studinya dismpulkan bahwa terdapat satu hubungan yang negatif di antara kenaikan upah dan tingkat pengangguran. Ketika tingkat pengangguran tinggi, maka tingkat kenaikan upah adalah rendah. Sebaliknya jika tingkat pengangguran rendah, maka tingkat kenaikan upah tinggi.

Penelitian lain yang serupa dengan ini dilakukan oleh Kholifah Anggrainy yang berjudul Analisis Dampak Kenaikan Upah Minimum Kota (UMK) terhadap Kesempatan Kerja dan Investasi (Studi Kasus Pada Kota Malang Periode 2001 - 2011). Hasil penelitian menunjukkan pengaruh UMK terhadap kesempatan kerja diperoleh nilai signifikansi sebesar $0,00<0,05$ dengan nilai koefisiennya adalah $-2,87$. Hal ini menyatakan bahwa UMK memiliki pengaruh negatif yang signifikan terhadap kesempatan kerja

\section{METODE PENELITIAN}

\section{Populasi Penelitian dan Metode Pengumpulan Data}

Penelitian ini dilakukan secara sensus dengan data sekunder berbentuk time series dari tahun 2004 sampai dengan 2013 yang merupakan data ketenagakerjaan setelah diberlakukannya Undang-Undang No 13 Tahun 2003 pada Provinsi DKI Jakarta.. Data ini diperoleh dari dari perpustakaan, website, jurnal atau dari laporan-laporan penelitian terdahulu. Jenis data yang digunakan adalah data sekunder. Data-data sekunder tersebut meliputi data mengenai besarnya upah minimum provinsi DKI, angka pengangguran, dan tingkat partisipasi angkatan kerja di Jakarta selama tahun 2004 sampai dengan 2013. Data sekunder dalam penelitian ini diperoleh dari lembaga atau instansi yang terkait dalam penelitian ini, antara lain Badan Pusat Statistik Jakarta dan Depnakertrans .

\section{Metode Analisis}

Analisis data dilakukan dengan bantuan Metode Korelasi sederhana dan Regresi Linear sederhana serta digunakan juga metode analisis deskriptif bertujuan untuk menggambarkan karakteristik dari sebuah sampel ataupun populasi yang teramati dan dapat digambarkan lewat tabel dan gambar sehingga dapat memberikan informasi yang baik yang pada akhirnya digunakan sebagai dasar pengambilan keputusan.

Kegunaan dari persamaan regresi ini adalah untuk mengetahui pola pengaruh antara variabel bebas terhadap variabel terikat. Adapun rumus umum dari regresi sederhana ini adalah sebagai berikut (Sugiyono, 2000: 145 )

$$
\mathbf{Y}=\mathbf{a}+\mathbf{b X}
$$

Keterangan:

$\mathrm{Y}=$ variabel tidak bebas)

$\mathrm{X}=$ variabel bebas

$\mathrm{a}=$ nilai konstanta

$\mathrm{b}=$ nilai koefisien regresi 
setelah nilai regresi diketahui, maka nilai $b$ dapat dihitung dengan menggunakan rumus sebagai berikut:

$$
\begin{aligned}
\mathrm{a} & =\Sigma \mathrm{Y}-\mathrm{b} \Sigma \mathrm{X} \\
\mathrm{b} & =\frac{\mathrm{n}(\Sigma \mathrm{XY})-(\Sigma \mathrm{X} \cdot \Sigma \mathrm{Y}}{\mathrm{n}(\Sigma \mathrm{X})^{2}-\Sigma \mathrm{X}^{2}}
\end{aligned}
$$

Keterangan:

$\mathrm{b}=$ nilai koefisien regresi

$\mathrm{Y}=$ variabel tidak bebas (produktivitas kerja )

$\mathrm{X}=$ variabel bebas (kompensasi dan disiplin kerja)

$\mathrm{a}=$ nilai konstanta

$\mathrm{n}=$ jumlah tahun penelitian

\section{Analisis Korelasi Sederhana}

Untuk mengetahui besarnya keeratan hubungan dari variabel kompensasi dan disiplin kerja terhadap variabel produktivitas kerja (Y), maka penulis akan menggunakan rumus sebagai berikut (Sugiyono, 2001: 216).

$$
\mathrm{r}=\frac{\mathrm{n}(\Sigma \mathrm{XY})-(\Sigma \mathrm{X}) \cdot(\Sigma \mathrm{Y})}{\sqrt{\left[\mathrm{n}\left(\Sigma \mathrm{X}^{2}\right)-(\Sigma \mathrm{X})^{2}\right] \cdot \sqrt{\left[n\left(\Sigma \mathrm{Y}^{2}\right)-(\Sigma Y)^{2}\right]}}}
$$

Sugiyono (2001: 216 ) pedoman yang dipakai untuk memberikan Interpretasi terhadap koefisien korelasi dapat dilihat pada tabel 2.

\section{Koefisien Penentu Sederhana}

Koefisien penentu sederhana adalah suatu koefisien untuk mengetahui kontribusi pengaruh variabel satu dengan variabel lain. Selanjutnya untuk mencari besarnya nilai koefisien determinasi antara variabel kenaikan upah buruh terhadap variabel tingkat pengangguran serta variabel kenaikan upah buruh terhadap variabel tingkat partisipasi angkatan kerja maka dapat digunakan rumus Koefisien Penentu (KP), dengan rumus umum (Sugiyono, 2000: 151) adalah:

$$
K P=r^{2} \times 100 \%
$$

Keterangan:

$\mathrm{KP}=$ koefisien penentu

$\mathrm{r} \quad=$ koefisien korelasi
Sedangkan untuk membuktikan kebenaran dari hipotesis yang telah penulis buat, maka dapat digunakan rumus sebagai berikut:

$$
\text { th }=\overline{-}
$$

$\mathrm{H}_{0}: \mathrm{r}=0$, tidak terdapat hubungan antara kenaikan upah minimum provinsi terhadap tingkat pengangguran di Jakarta

$\mathrm{H}_{1}: \mathrm{r} \neq 0$, terdapat hubungan antara kenaikan upah minimum provinsi terhadap tingkat pengangguran di Jakarta

$\mathrm{H}_{0}: \mathrm{r}=0$, tidak terdapat hubungan antara kenaikan upah minimum provinsi terhadap tingkat partisipasi angkatan kerja di Jakarta

$\mathrm{H}_{2}: \mathrm{r} \neq 0$, terdapat hubungan antara kenaikan upah minimum provinsi terhadap tingkat partisipasi angkatan kerja di Jakarta

Operasionalisasi Variabel.

Dalam penelitian ini penulis menjadikan variable kenaikan upah sebagai variabel bebas (X) dan variabel tingkat pengangguran serta variabel tingkat partisipasi angkatan kerja sebagai variabel terikat (Y1 dan Y2). Hubungan antara ketiga variabel tersebut dapat digambarkan pada gambar 2 berikut.

\section{Definisi Operasional}

Upah adalah hak pekerja/buruh yang diterima dan dinyatakan dalam bentuk uang sebagai imbalan dari pengusaha atau pemberi kerja kepada pekerja/buruh yang ditetapkan dan dibayarkan menurut suatu perjanjian kerja, kesepakatan, atau peraturan perundang undangan, termasuk tunjangan bagi pekerja/buruh dan keluarganya atas suatu pekerjaan dan/atau jasa yang telah atau akan dilakukan.

$$
\text { Upah Minimum Provinsi yang }
$$
selanjutnya disingkatUMP adalah upah minimum yang berlaku untuk seluruh kabupaten / Kota di satu Provinsi dan ditetapkan oleh Gubernur.

Penganggur adalah mereka yang tidak bekerja dan sedang mencari pekerjaan menurut referensi waktu tertentu atau mereka yang pernah bekerja / dibebastugaskan tetapi sedang 
Tabel 2. Pedoman Interpretasi Koefisien Korelasi

\begin{tabular}{|c|c|}
\hline Interval Koefisien & Tingkat hubungan \\
\hline $0.001-0.200$ & Sangat lemah \\
$0.201-0.400$ & Lemah \\
$0.401-0.600$ & Cukup kuat \\
$0.601-0.800$ & Kuat \\
$0.801-1.000$ & Sangat kuat \\
\hline
\end{tabular}

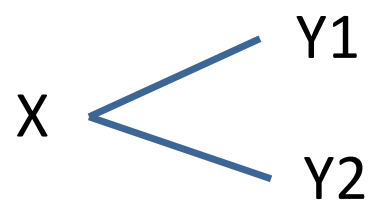

Gambar 2. Operasionalisasi Variabel

menganggur dan mencari pekerjaan. Indikator yang digunakan untuk mengukur pengangguran adalah Tingkat Pengangguran Terbuka (TPT).

Tingkat Partisipasi Kerja (TPAK) merupakan rasio antara penduduk yang termasuk angkatan kerja (bekerja atau mencari pekerjaan) dengan total penduduk yang masuk usia kerja.

\section{HASIL DAN PEMBAHASAN}

Penelitian ini dilakukan untuk memperoleh gambaran tentang upah minimum provinsi terkait dengan tingkat pengangguran dan tingkat partisispasi angkatan kerja di Jakarta selama 10 tahun dari tahun 2004 sampai dengan 2013.

Data yang dibutuhkan merupakan data sekunder yang diperoleh dari beberapa sumber antara lain dari Biro Pusat Statistik Provinsi DKI Jakarta , Dinas Ketenagakerjaan dan Transmigrasi Provinsi DKI Jakarta. Data yang diambil adalah data tentang Upah Minimum Provinsi DKI Jakarta, Data Ketenagaakerjaan Provinsi DKI yang mencakup tentang data penduduk usia 15 tahun ke atas laki-laki dan perempuan, jumlah tenaga kerja, jumlah angkatan kerja, jumlah penduduk yang bekerja, dan jumlah pengangguran terbuka di Jakarta sejak tahun 2004 sampai dengan tahun 2013. Data kemudian diolah untuk mendapatkan angka Tingkat Partisispasi Angkatan Kerja dan angka Tingkat Pengangguran Terbuka Di Jakarta. ( Hasil dilampirkan).

\section{Gambaran Upah Minimum Provinsi DKI Jakarta tahun 2004 -2013}

Kebijakan pengupahan di Provinsi DKI Jakarta ditetapkan dengan Peraturan Gubernur yang didasarkan pada Undang-undang No.13 tahun 2003 tentang Ketenagakerjaan dan Keputusan Presiden No. 107 Tahun 2004 tentang dewan pengupahan dan juga Peraturan Menteri Tenaga Kerja dan Transmigrasi tentang upah minimum serta peraturan-peraturan lain yang terkait dengan ketenagakerjaan.

Meski sering terjadi konflik antara pekerja dan pengusaha dalam proses penetapan upah minimum, yang biasanya diikuti dengan demo buruh, Upah Minimum Provinsi DKI Jakarta setiap tahun mengalami kenaikan. Kenaikan upah minimum ini diharapkan dapat memenuhi kebutuhan standar hidup layak tenaga kerja. Standar hidup layak pekerja selalu berubah dengan adanya penambahan 
komponen-komponen kebutuhan yang dianggap penting untuk kelayakan hidup tenaga kerja.

Sebelum menetapkan Upah Minimum Propinsi, Dewan Pengupahan yang terdiri dari perwakilan serikat pekerja, pengusaha, pemerintah, dan pihak netral dari akademisi akan melakukan survei Kebutuhan Hidup Layak (KHL).

Kebutuhan Hidup Layak yang selanjutnya disingkat KHL adalah standar kebutuhan yang harus dipenuhi oleh seorang pekerja/buruh lajang untuk dapat hidup layak baik secara fisik, non fisik dan sosial, untuk kebutuhan 1 bulan.

Sejak diluncurkannya UU No. 13 Tahun 2003 tentang ketenagakerjaan, Pemerintah menetapkan standar KHL sebagai dasar dalam penetapan Upah Minimum seperti yang diatur dalam pasal 88 ayat 4.Peraturan mengenai KHL, diatur dalam UU No.13 Tahun 2003 tentang ketenagakerjaan. Pembahasan lebih dalam mengenai ketentuan KHL, diatur dalam Keputusan Menteri Tenaga Kerja No. 17 Tahun 2005 tentang komponen dan pentahapan pencapaian kebutuhan hidup layak. Namun, Keputusan Menteri Tenaga Kerja No. 17 Tahun 2005 direvisi oleh Keputusan Menteri Tenaga Kerja No. 13 Tahun 2012 tentang perubahan penghitungan kebutuhan hidup layak (KHL).

Jumlah jenis kebutuhan yang semula 46 jenis dalam Keputusan Menteri Tenaga Kerja No. 17 tahun 2005 menjadi 60 jenis KHL dalam Keputusan Menteri Tenaga Kerja No. 13 tahun 2012. Penambahan baru sebagai berikut: 1) Ikat pinggang, 2) Kaos kaki, 3) Deodorant $100 \mathrm{ml} / \mathrm{g}$, 4) Seterika 250 watt, 5) Rice cooker ukuran $1 / 2$ liter, 6) Celana pendek, 7) Pisau dapur, 8) Semir dan sikat sepatu, 9) Rak piring portable plastic, 10) Sabun cuci piring, (colek) 500 gr per bulan,

11) Gayung plastik ukuran sedang, 12) Sisir, 13) Ballpoint/pensil, 14) Cermin 30 x $50 \mathrm{~cm}$.

Standar KHL terdiri dari beberapa komponen yaitu : (1) Makanan \& Minuman (11 items), (2) Sandang (13 items), (3) Perumahan (26 items), (4) Pendidikan (2 item), (5) Kesehatan (5 items), (6) Transportasi (1 item), (7) Rekreasi dan Tabungan (2 item).

Upah minimum provinsi DKI Jakarta tahun 2004-2013 dapat dilihat pada tabel 3.

\section{Gambaran Keadaan Tingkat Pengangguran Terbuka dan Tingkat Partisipasi Angkatan Kerja di Provinsi DKI Jakarta tahun 2004 - 2013}

Tingkat Pengangguran Terbuka (TPT) merupakan indikator yang menggambarkan persentase angkatan kerja yang tidak bekerja dan sedang mencari pekerjaan atau mempersiapkan suatu usaha, atau mereka yang tergolong angkatan kerja namun tidak terserap dalam pasar kerja. TPT diperoleh dengan cara membagi jumlah angkatan kerja yang menganggur dibagi dengan jumlah angkatan kerja.

Tingkat Partisipasi angkatan Kerja (TPAK) merupakan indikator yang menggambarkan penduduk usia kerja yang terlibat aktif dalam kegiatan ekonomi. Angka ini diperoleh dengan membagi jumlah angkatan kerja dibagi dengan jumlah penduduk usia 15 tahun ke atas.

Penduduk yang termasuk dalam angkatan kerja adalah penduduk usia kerja (15 tahun ke atas) yang bekerja, atau punya pekerjaan namun sementara tidak bekerja dan pengangguran.

Penduduk yang termasuk bukan angkatan kerja adalah penduduk usia kerja 15 tahun ke atas yang masih sekolah, mengurus rumah tangga atau melakukan kegiatan lainnya selain kegiatan pribadi.

Dari data kependudukan yang diperoleh dari BPS DKI Jakarta dan Depnakertran telah diolah hasil seperti pada tabel 4.

\section{Pengaruh Kenaikan Upah Minimum Provinsi Terhadap Tingkat Pengangguran Di Jakarta}

\section{Analisis Regresi}

Untuk mengetahui pengaruh besarnya Upah Minimum Provinsi terhadap tingkat pengangguran di Jakarta maka dipergunakan rumus regresi sederhana sebagai berikut:

$$
\begin{aligned}
& \mathbf{Y}=\mathbf{a}+\mathbf{b x} \\
& \mathbf{a}=\Sigma \mathbf{Y}-\mathbf{b} \Sigma \mathbf{X} \\
& \mathbf{b}=\frac{\mathbf{n}(\Sigma \mathbf{X Y})-(\Sigma \mathbf{X} \cdot \Sigma \mathbf{Y})}{\mathbf{n}(\Sigma \mathbf{X})^{2}-\Sigma \mathbf{X}^{2}}
\end{aligned}
$$


Tabel 3. Upah Minimum Provinsi DKI Jakarta ( 2004 -2013)

\begin{tabular}{|l|c|c|}
\hline \multirow{2}{*}{ Tahun } & \multicolumn{2}{|c|}{ Upah Minimum Provinsi } \\
\cline { 2 - 3 } & $\mathrm{Rp}$ & Kenaikan $(\%)$ \\
\hline 2004 & 671.550 & 6.3 \\
\hline 2005 & 711.843 & 6,0 \\
\hline 2006 & 819.100 & 15,1 \\
\hline 2007 & 900.560 & 9,9 \\
\hline 2008 & 972.605 & 8,0 \\
\hline 2009 & 1.069 .865 & 10,0 \\
\hline 2010 & 1.118 .009 & 4.5 \\
\hline 2011 & 1.290 .000 & 15,38 \\
\hline 2012 & 1.529 .150 & 18,53 \\
\hline 2013 & 2.200 .000 & 43,88 \\
\hline
\end{tabular}

Sumber: BPS DKI Jakarta dan Dinas Tenaga Kerja \&Trans. Provinsi DKI Jakarta

Tabel 4. Tingkat Pengangguran Terbuka dan Tingkat Partisipasi Angkatan Kerja di Jakarta tahun $2004-2013$

\begin{tabular}{|c|c|r|r|r|}
\hline Tahun & $\begin{array}{c}\text { Tingkat } \\
\text { Pengangguran } \\
\text { Terbuka } \\
(\mathrm{TPT}) \\
(\%)\end{array}$ & $\begin{array}{c}\text { Kenaikan } \\
(\%)\end{array}$ & $\begin{array}{c}\text { Tingkat } \\
\text { Partisipasi } \\
\text { Angkatan } \\
\text { Kerja } \\
\text { (TPAK) } \\
(\%)\end{array}$ & $\begin{array}{c}\text { Kenaikan } \\
(\%)\end{array}$ \\
\hline 2004 & 14.7006 & -0.1570 & 61.9329 & 1.4804 \\
\hline 2005 & 14.7305 & 0.0299 & 63.0769 & 1.1440 \\
\hline 2006 & 14.3146 & -0.4159 & 62.7204 & -0.3565 \\
\hline 2007 & 13.268 & -1.0466 & 61.0403 & -1.6801 \\
\hline 2008 & 12.1637 & -1.6043 & 68.6778 & 7.6375 \\
\hline 2009 & 12.1453 & -0.0184 & 66.5957 & -2.0821 \\
\hline 2010 & 11.0542 & -1.0911 & 67.8339 & 1.2382 \\
\hline 2011 & 7.2723 & -3.7819 & 68.5344 & 0.7005 \\
\hline 2012 & 9.8717 & 2.5994 & 71.56 & $3 . .0256$ \\
\hline 2013 & 9.0187 & -0.8530 & 68.0879 & -3.4721 \\
\hline
\end{tabular}

Keterangan :

$\mathrm{Y}=$ tingkat pengangguran terbuka

$\mathrm{a}=$ bilangan konstanta

$\mathrm{b}=$ koefisien regresi

$\mathrm{X}=$ upah minimum provinsi

$\mathrm{N}$ = banyaknya data

Dari data Upah Minimum Provinsi dan Tingkat Pengangguran Terbuka di atas dan dengan bantuan program excel dengan menggunakan fungsi statistik intercept dan slope pada program excel diperoleh $\mathrm{a}=$ 15,54229 dan $\mathrm{b}=-3,4899 \mathrm{E}-06$ sehingga diperoleh persamaan regresi sebagai berikut:

$$
Y=15,54229-3,4899 E-06
$$

Dari persamaan regresi di atas dapat disimpulkan bahwa jika upahminimum provinsi dinaikkan sebesar Rp1.000.000,00 maka tingkat pengangguran terbuka akan turun sebesar 3,4899\%. 


\section{Koefisien Korelasi Sederhana}

Untuk mencari nilai koefisien korelasi sederhana penulis menggunakan fungsi statistik pada program excel yaitu Correl dan diperoleh $r=-0,7841$. Hal ini menunjukkan bahwa derajat hubungan antara upah minimum provinsi dengan tingkat pengangguran terbuka adalah kuat.

\section{Koefisien Determinasi}

Setelah nilai koefisien korelasi diketahui, maka nilai koefisien determinasi ( Koefisien Penentu) dapat dicari dengan menggunakan rumus:

$$
\begin{aligned}
& K P=r^{2} \\
& K P=(-0,78)^{2} \\
& K P=0,612
\end{aligned}
$$

Dari hasil perhitungan di atas maka dapat diartikan bahwa faktor atau variabel upah minimum provinsi mempunyai pengaruh sebesar $61,2 \%$ terhadap Tingkat pengangguran terbuka di Provinsi DKI Jakarta. Sedangkan $38,8 \%$ dipengaruhi oleh variabel lain.

\section{Uji Hipotesis}

Untuk menguji hipotesis yang mengatakan bahwa upah minimum provinsi berpengaruh terhadap tingkat pengangguran terbuka,

$\mathrm{H}_{0}: \mu=0$ tidak ada hubungan antara upah minimum provinsi dengan tingkat pengangguran di provinsi DKI Jakarta.

Ha $: \mu \neq 0$ ada hubungan antara upah minimum provinsi dengan tingkat pengangguran di provinsi DKI Jakarta.

Dalam pengujian ini digunakan distribusi " $\mathrm{t}$ " dengan rumus sebagai berikut:

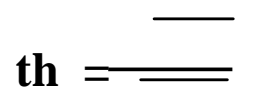

telah diketahui :

$\mathrm{r}=-0,78$

$\mathrm{r}^{2}=0,612$

$\mathrm{n}=10$

maka dapat dicari t hitung

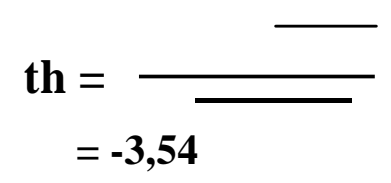

Harga $\mathrm{t}$ hitung selanjutnya diperbandingkan dengan haarga $t$ tabel untuk kesalahaan $5 \%$ uji dua pihak dan $\mathrm{dk}=\mathrm{n}-2=8$ maka diperoleh $\mathrm{t}$ tabel $=2,306$. Karena $\mathrm{T}$ hitung lebih kecil dari $\mathrm{T}$ tabel, maka H0 ditolak dan Ha diterima.

\section{Pengaruh Upah Minimum Provinsi Terhadap Tingkat Partisispasi Angkatan Kerja di Provinsi DKI Jakarta}

\section{Analisis Regresi}

Dari data upah minimum provinsi dan Tingkat Partisipasi Angkatan Kerja di atas dan dengan bantuan program excel dengan menggunakan fungsi statistik intercept dan slope pada program excel diperoleh $\mathrm{a}=60,2688$ dan $\mathrm{b}=5,08497 \mathrm{E}$ 06 sehingga diperoleh persamaan regresi sebagai berikut:

$$
Y=60,2688+5,08497 E-06 X
$$

Dari persamaan regresi di atas dapat disimpulkan bahwa jika upah minimum provinsi dinaikkan sebesar Rp. 1.000.000,- maka Tingkat partisispasi Angkatan Kerja akan meningkat sebesar 5,08497\%.

\section{Koefisien Korelasi Sederhana}

Untuk mencari nilai koefisien korelasi sederhana penulis menggunakan fungsi statistik pada program excel yaitu Correl dan diperoleh $\mathrm{r}$ $=0,658$. Hal ini menunjukkan bahwa derajat hubungan antara upah minimum provinsi dengan tingkat partisipasi angkatan kerja adalah kuat.

\section{Koefisien Determinasi}

Setelah nilai koefisien korelasi diketahui, maka nilai koefisien determinasi ( Koefisien Penentu) dapat dicari dengan menggunakan rumus:

$$
\begin{aligned}
& K P=r^{2} \\
& K P=0,658^{2} \\
& K P=0,433
\end{aligned}
$$


Dari hasil perhitungan di atas maka dapat diartikan bahwa faktor atau variabel upah minimum provinsi mempunyai pengaruh sebesaar 43,3 \% terhadap Tingkat Partisipasi angkatan Kerja di Provinsi DKI Jakarta. Sedangkan 56,7 \% dipengaruhi oleh variabel lain.

\section{Uji Hipotesis}

Untuk menguji hipotesis yang mengatakan bahwa upah minimum provinsi berpengaruh terhadap tingkat partisipasi angkatan kerja.

$\mathrm{H}_{0}: \mu=0$ tidak ada hubungan antara upah minimum provinsi dengan tingkat Partisipasi angkatan kerja di provinsi DKI Jakarta.

Ha: $\mu \neq 0$ ada hubungan antara upah minimum provinsi dengan tingkat Partisipasi angkatan kerja di provinsi DKI Jakarta.

Dalam pengujian ini digunakan distribusi " $\mathrm{t}$ " dengan rumus sebagai berikut:

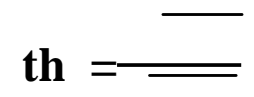

dimana telah diketahui :

$\mathrm{r}=0,658$

$\mathrm{r}^{2}=0,433$

$\mathrm{n}=10$

maka dapat dicari t hitung

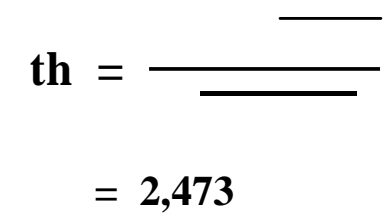

Harga $t$ hitung selanjutnya diperbandingkan dengan harga $t$ tabel untuk kesalahaan $5 \%$ uji dua pihak dan $\mathrm{dk}=\mathrm{n}-2=8$ maka diperoleh $\mathrm{t}$ tabel $=2,306$. Hal ini berarti dari hasil perhitungan terlihat bahwa t hitung lebih besar dari t tabel, sehingga hipotesis yang menyatakan bahwa tidak ada hubungan positif antara upah minimum provinsi dengan tingkat pengangguran terbuka di Jakarta tidak dapat diterima atau terdapat hubungan yang positif antara upah minimum provinsi dengan tingkat partisipasi angkatan kerja di provinsi DKI Jakarta.

\section{Simpulan}

1. Analisis regresi terhadap variabel Upah Minimum Provinsi dan Tingkat Pengangguran di Jakarta dihasilkan $\mathrm{Y}=$ 15,54229 - 3,4899E-06 artinya apabila variabel UMP dinaikkan sebesar Rp. 1.000.000,- maka akan menurunkan tingkat pengangguran sebesar 3,4899\%. Koefisien korelasi (r) sebesar - 0,78 yang artinya bahwa antara UMP dengan TPT mempunyai hubungan yang kuat dan negatif. Sedangkan koefisien determinasi atau koefisien penentu sebesar $0,612=61,2 \%$ artinya pengaruh yang diberikan oleh UMP terhadap tingkat pengangguran adalah sebesar 61,2 \% sedangkan sisanya 31,8\% dipengaruhi oleh faktor-faktor lainnya.

2. Analisis regresi terhadap variabel Upah Minimum Provinsi dan Tingkat Paartisispasi Angkatan Kerja di Jakarta dihasilkan Y = $60,2688+5,08497 \mathrm{E}-06 \mathrm{X}$ artinya apabila variabel UMP, dinaikkan sebesar Rp. 1.000.000,- maka akan menaikkaan tingkat partisipasi angkatan kerja sebesar 5,08497

$\%$. Koefisien korelasi (r) sebesar 0,658 yang artinya bahwa antara UMP dengan TPAK mempunyai hubungan yang kuat dan positif. Sedangkan koefisien determinasi sebesar $0,433=43,3 \%$ artinya pengaruh yang diberikan oleh UMP terhadap tingkat partisipasi angkatan kerja adalah sebesar $43,3 \%$ sedangkan sisanya 56,7 \% dipengaruhi oleh faktor-faktor lainnya.

3. Kenaikkan Upah minimum Provinsi dapat menurunkan tingkat pengangguran dan menaikkan tingkat partisipasi angkatan kerja di Jakarta.

Untuk menurunkan tingkat pengangguran di Jakarta maka sebaiknya upah minimum provinsi besarnya selalu disesuaikan dengan standar hidup yang layak. Menurunnya tingkat pengangguran akan berdampak luas terhadap masalah sosial, ekonomi, dan keamanan di Jakarta. Pemerintah harus berusaha untuk menyesuaikan Upah Minimum Provinsi agar sesuai dengan standar hidup layak sehingga 
akan dapat mendorong penduduk usia produktif untuk aktif dalam kegiatan ekonomi atau bekerja yang pada akhirnya akan meningkatkan tingkat partisipasi kerja dan menurunkan tingkat pengangguran.

\section{DAFTAR PUSTAKA}

Ardana, I Komang, dkk. 2012. Manajemen Sumber Daya Manusia. Yogyakarta: Graha Ilmu Yogyakarta

Mankiw, Gregory. 2006. Makroekonomi. Erlangga.

Peraturan Menteri Tenaga KerjaDan Transmigrasi Nomor 7 Tahun 2013 tentang upah minimum.

Pergub DKI tentang Upah Minimum Provinsi

Rahardja, Pratama dan Manurung, Mandala. 2008. Pengantar Ilmu ekonomi.

\section{Lembaga Penerbit Fakultas}

EkonomiUniversitas Indonesia.

Rahardja, Pratama dan Manurung,

Mandala. 2005. Teori Ekonomi Makro.

Lembaga Penerbit Fakultas

Ekonomi Universitas Indonesia.

Sukirno, Sadono. Makro Ekonomi. 2006.

Teori Pengantar. Jakarta:

PT.Rajagrafindo Persada.

Bachrun, Saifuddin. 2012. DesainPengupahan untuk Hubungan Industrial Dalam Praktek. Jakarta: PPM.

Sedarmayanti. 2011. Manajemen Sumber Daya Manusia. Bandung: PT Refika Aditama.

Sugiyono, Prof. Dr. 2013. Metode Penelitian Bisnis, CV. Alfabeta.

UU RI No.13 Tahun 2003 tentang ketenagakerjaan 